\title{
Ascidian distribution provides new insights to help define the biogeographic provinces in the South American Region
}

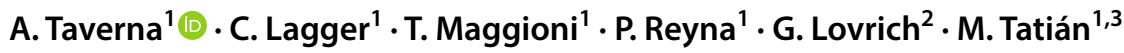

Received: 14 March 2017 / Revised: 22 January 2018 / Accepted: 23 January 2018

c) Springer-Verlag GmbH Germany, part of Springer Nature 2018

\begin{abstract}
The validity and size of the biogeographic Magellan Province of marine organisms have been the focus of discussion of many authors. The distribution of fish and other organisms has revealed a lack of homogeneity in the area, which has also been interpreted as comprising four different Provinces: Southern Chile (SCH), Tierra del Fuego (TDF), Southern Argentina (SAR), and the Malvinas/Falkland Islands (MAI). For the first time, we assess the ascidian fauna of this region to determine if the distribution of benthic sessile filter feeders corresponds to these biogeographic provinces. Ascidian species richness and percentages of endemism for these four areas were estimated using data from the literature and new sampling. Biogeographic affinities among SCH, TDF, SAR, and MAI were also calculated. The species Pyura pilosa, Molgula malvinensis, and Molgula manhattensis, the latter frequently considered as invasive, were found for the first time on the TDF shelf. The highest ascidian species richness was found in TDF (70 species), while the percentages of endemism greater than 10\% (the minimum to qualify an area as a province) were found in TDF (15.7\%) and SCH (11.1\%). SAR and MAI showed the lowest percentages of endemism and the strongest affinity. Based on percentages of endemism, faunal affinities, and differences among the four provinces, we propose a separation of the South American Region into three Provinces: SCH, TDF, and SAR/MAI. Continued sampling of ascidians is considered to be particularly important, given the potential spread of invasive species throughout this region.
\end{abstract}

Keywords Ascidiacea $\cdot$ Biogeography $\cdot$ Magellan $\cdot$ South American Region $\cdot$ Biological invasion

Electronic supplementary material The online version of this article (https://doi.org/10.1007/s00300-018-2272-y) contains supplementary material, which is available to authorized users.

A. Taverna

anabelataverna@gmail.com

1 Consejo Nacional de Investigaciones Científicas y Técnicas (CONICET), Instituto de Diversidad y Ecología Animal (IDEA), Av. Vélez Sarsfield 299, 5000 Córdoba, Argentina

2 Consejo Nacional de Investigaciones Científicas y Técnicas (CONICET), Centro Austral de Investigaciones Científicas (CADIC), Bernardo Houssay 200, Ushuaia, Tierra del Fuego, Argentina

3 Ecología Marina, Facultad de Ciencias Exactas, Físicas y Naturales, Universidad Nacional de Córdoba, Córdoba, Argentina

\section{Introduction}

The Magellan Province comprises the SW Atlantic and SE Pacific from $40^{\circ} \mathrm{S}$ to the northern extension of the Antarctic Polar Front and contains a unique assemblage of marine fauna. It is considered a biogeographic entity in the distribution of many organisms (Hedgpeth 1969; Monniot and Monniot 1983). According to Spalding et al. (2007), the Magellan Province extends along the coast and shelf of the southern tip of South America, from the northern Patagonian gulfs $\left(40^{\circ} \mathrm{S}\right)$ to the channels and fjords of Southern Chile $\left(40^{\circ} \mathrm{S}\right)$, including the Malvinas/Falkland Islands. More recently, Miloslavich et al. (2011) stated that the Magellan Province should also include the deep waters of the shelf and slope of Buenos Aires Province and Uruguay. This is due to the influence of the Malvinas Current, a strong cold water current system, which extends across the slope and partly onto the deeper section of the outer shelf (Legeckis and Gordon 1982). On the Patagonian shelf (Argentine Sea), the Malvinas Current flows along the edge of the slope, reaching 
as far as $36^{\circ} \mathrm{S}$ (Piola and Rivas 1997). This circulation is found to favor the dispersal of Sub-Antarctic fauna into the north (Balech and Ehrlich 2008).

Based on the distribution pattern and endemism of fish, anemone, polychaete, and crustacean species, Briggs and Bowen (2012) proposed a world biogeographic division showing the evolutionary relationships of different marine biota, as a framework for the establishment of ecological units in a context of conservation. This general division was recognized later by several authors (Robertson and Cramer 2014; Cowman 2014; Hattab et al. 2015; Barroso et al. 2016). In that study, instead of the Magellan Province proposed by Hedgpeth (1969), the authors proposed the existence of a biogeographic region characterized by cold-temperate waters: the South American Region. Within it, they postulated four different faunal Provinces: Southern Chile, Tierra del Fuego, Southern Argentina, and the Malvinas/ Falkland Islands. This distribution scheme represents a significant change from the previous division, which assumed homogeneous marine fauna for the entire Magellan area.

The boundaries of biogeographic regions are neither fixed, nor do they have the same validity for all the taxa involved (Hedgpeth 1969; Briggs 1995; Spalding et al. 2007; Miloslavich et al. 2011; Briggs and Bowen 2012). Briggs (1974) divided the continental shelves around the world into a series of large biogeographic regions that, in turn, contain smaller biogeographic provinces, each defined on the basis of phylum-level endemism. Optimal fitness through a range of temperature, salinity, light penetration, and water movement varies according to taxa, egg type, duration of larval life, the capacity of larvae to disperse and to find a suitable substrate for their adult stage (Clarke 1996). Besides geological evolution, different water masses, diversity of coastal topography, and shelf size are the main factors that promote differences in species distribution (Spalding et al. 2007).

Ascidians are soft-bodied colonial or solitary animals found in all oceans (Van Name 1945). They are important members of benthic communities in terms of diversity (c. 3000 species according to Shenkar and Swalla 2011) and abundance and, as they are filter feeders, they have an important role in bentho-pelagic coupling (Coppari et al. 2014). The distribution of ascidians is determined by the dispersal capability of their lecithotrophic larvae and the passive transportation of these larvae by marine currents (Ayre et al. 1997). However, an increase of shipping traffic also allows propagules to be distributed accidentally, as fouling forms on ship hulls, oil-drilling platforms, and aquaculture farms (Zhan et al. 2015). It has been proposed that this humandriven transport is responsible for the presence of exotic species in new locations (Lambert 2007; Locke and Carman 2009; Zhan et al. 2015). The southern tip of South America (and the Magellan Province) has been poorly studied (Orensanz et al. 2002) until now. However, the area has been highlighted as vulnerable to marine invasion, including that of ascidians (Orensanz et al. 2002; Castilla et al. 2005; Tatián et al. 2010; Schwindt et al. 2014; Pereyra et al. 2015, 2017).

Variations of this biogeographic region and its provinces have been proposed by a number of different studies, such as Kott (1969a), who proposed, based on ascidians, a division in which the Magellan Province, including Patagonia and the Malvinas/Falkland Islands (two particularly poorly studied areas in terms of sampling), would be a northern part of the Sub-Antarctic Region. Ramos-Esplá et al. (2005) recognized the Magellan Region as an area ranging from $42^{\circ} \mathrm{S}$ in the SE Pacific to $34^{\circ} \mathrm{S}$ in the SW Atlantic (Río de la Plata). Primo and Vázquez (2007) considered the South American Region as extending from Chiloé Island to the Valdés Peninsula, including the Malvinas/Falkland Islands. Despite differing in their denomination and extent, all of these division criteria judged the Magellan area to be a biogeographic extension that is homogeneous for ascidian distribution.

Ascidiacea is an excellent group in which to carry out biogeographic studies (Ramos-Esplá et al. 1992; Naranjo et al. 1998; Primo and Vázquez 2007, 2009, 2014; Moreno et al. 2014; Ma et al. 2017), because they have a short-lived larval stage, which restricts dispersion and colonization of new areas and therefore the gene-flow between populations (Kott 1974), making them good indicators of vicariant events. Our aim in this study is to analyze previous and new data on the species richness, endemism, and distribution of ascidians within the Magellan area, to assess whether it is a homogeneous biogeographic province (Kott 1969a; Ramos-Esplá et al. 2005; Primo and Vázquez 2007) or, as was stated by Briggs and Bowen (2012), it is better separated into four Provinces: Southern Chile, Tierra del Fuego, Southern Argentina, and the Malvinas/Falkland Islands, all constituting the South American Region.

\section{Materials and methods}

Species distribution data were obtained from a thorough taxonomic literature search (Van Name 1945; Millar 1960; Kott 1969b, 1971; Monniot and Monniot 1983; Sanamyan and Schories 2003; Ramos-Esplá et al. 2005; Tatián et al. 2005, 2010; Primo and Vázquez 2007, 2014; Lagger et al. 2009; Schories et al. 2015; Turon et al. 2016a) and new sampling carried out during the "CONCACEN II" campaign in December 2009, on board R.V. "Puerto Deseado". The area under study covered the Atlantic continental shelf off Tierra del Fuego (including the Beagle Channel), Staten Island, and the proximity of the Burdwood Bank (Namuncurá Marine Protected Area, NMPA). Samples were taken from 13 stations, using bottom fishing nets at depths between 49 and 149 m (Fig. 1a). Captured 

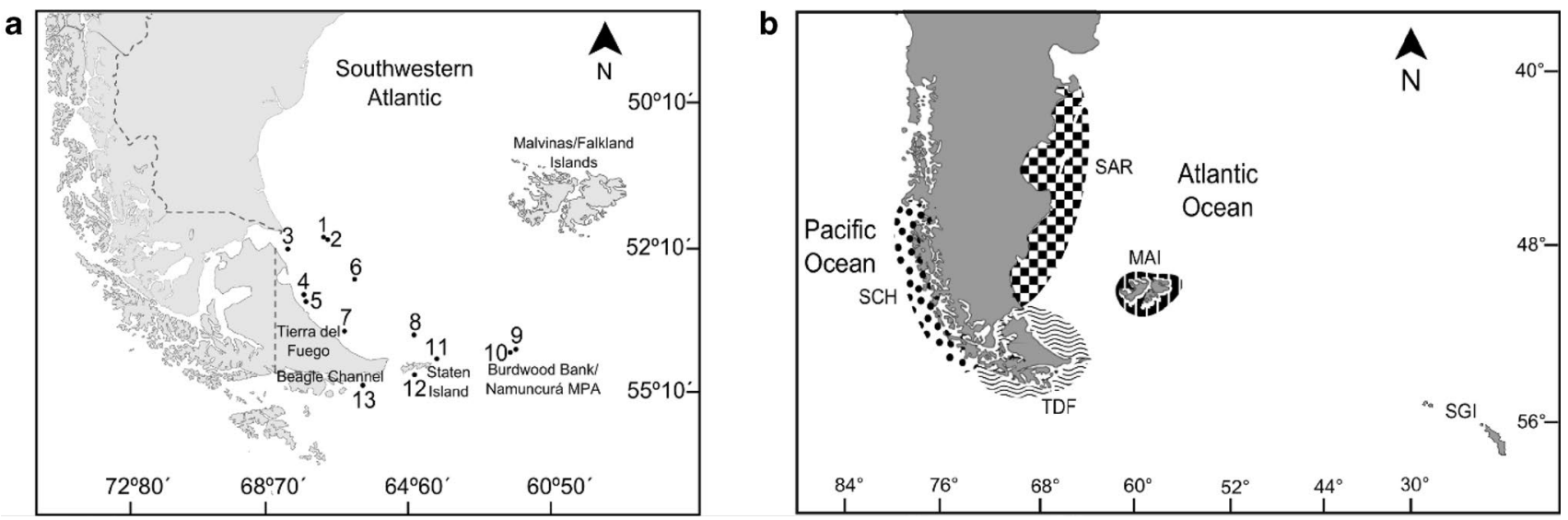

Fig. 1 a CONCACEN II campaign: sampling sites in Tierra del Fuego shelf; b the South American Region. SCH Southern Chile, TDF Tierra del Fuego, SAR Southern Argentina, MAI Malvinas/Falkland Islands, SGI South Georgia Islands. Adapted from Briggs and Bowen (2012)

ascidians were relaxed in menthol for at least $2 \mathrm{~h}$ and later fixed in a $2.5 \%$ formaldehyde solution in seawater. The examined material is housed in the collection of the Museo de Zoología, Universidad Nacional de Córdoba, Argentina. Distributional information for the ascidian species was obtained from the Global Biodiversity Information Facility database (GBIF.org 2017).

Analyses were carried out on the four provinces of the South American Region proposed by Briggs and Bowen (2012) for the Southern Hemisphere temperate-cold and polar waters. These were Southern Chile $(\mathrm{SCH})$, Tierra del Fuego (TDF), Southern Argentina (SAR), and the Malvinas/Falkland Islands (MAI) (Fig. 1b). Only ascidians distributed in waters shallower than $500 \mathrm{~m}$ were considered in this study, as greater depths are expected to present wider distribution of species, due to the homogeneous conditions present in these environments (McClain and Hardy 2010). For each province, the total species richness $\left(\mathrm{S}^{\prime}\right)$ and percentages of endemism (the number of endemic species in a given area $\times 100 / S^{\prime}$ ) were calculated.

Multivariate analyses were used to determine species affinities between provinces based on a presence-absence matrix. The South Georgia Islands, an area considered a bridge for the distribution of marine organisms between the Magellan Province and the Antarctic Peninsula (Arntz 2005; Hogg et al. 2011), were included as an outgroup in all the analyses. These islands are at the northern limit of the Polar Front, one of the strongest biogeographic boundaries worldwide, separating the colder Southern Ocean polar waters from the warmer temperate waters in adjacent regions (Clarke and Crame 1989). Classification analysis was performed using the Bray-Curtis similarity index and the UPGMA clustering method. Nonmetric multidimensional scaling (NMDS) of ascidian species from the five areas was performed.
Permutational multivariate analysis of variance (PERMANOVA) was used to define statistical differences between pairs of provinces, based on the Bray-Curtis distance measure. The significance was computed by permutation of group membership, with 9999 replicates (Anderson 2001). In addition, co-occurrence of species was evaluated by means of the Kulczynski-2 similarity index. This index of biogeographical affinity was previously used for ascidians in the study area (Monniot and Monniot 1983; Tatián et al. 2005). PAST 3.16 free statistical software was used for these analyses (Hammer et al. 2001).

Rarefaction curves were performed in all the provinces considered, including the outgroup, to evaluate sampling intensity in these areas, using " $\mathrm{R}$ " (R Development Core Team 2016). They were divided into grid cells of $2^{\circ}$ latitude by $2^{\circ}$ longitude (Clarke et al. 2007). Each grid cell was considered a sampling station, containing all the species recorded in that area. Records of the same species were counted only once within each grid cell.

\section{Results}

Using previous research and the new records from this sampling campaign, 118 ascidian species (561 occurrences) in total were found distributed throughout the area comprised by the four provinces of the South American Region and the South Georgia Islands (Online Resource 1). The new campaign samples yielded 12 species from 163 specimens (Table 1).

Species richness and percentage of endemism for each province are shown in Table 2. The greatest species richness (70 species) and the highest endemism (15.7\%) corresponded to TDF. Despite its high species richness (65 species), SGI exhibited zero endemism, while the lowest species 
Table 1 Distribution and bathymetric range of the species found at the CONCACEN II campaign

\begin{tabular}{|c|c|c|c|}
\hline Species & Known distribution range & $\begin{array}{l}\text { Known bathym- } \\
\text { etric distribution } \\
\text { (m) }\end{array}$ & Present study/new records* \\
\hline $\begin{array}{l}\text { Cnemidocarpa nordenskjoldi } \\
\text { (Michaelsen, 1898) }\end{array}$ & $\begin{array}{l}\text { Buenos Aires, Patagonia (Argentina } \\
\text { and Chile), Malvinas/Falkland } \\
\text { Islands, Tierra del Fuego, Scotia Sea, } \\
\text { South Shetland Islands, Antarctica }\end{array}$ & $15-1500$ & $\begin{array}{l}\text { Tierra del Fuego, Staten Island, BB/ } \\
\text { NMPA }\end{array}$ \\
\hline $\begin{array}{l}\text { Cnemidocarpa verrucosa (Lesson, } \\
1830 \text { ) }\end{array}$ & $\begin{array}{l}\text { Patagonia (Argentina and Chile), } \\
\text { Malvinas/Falkland Islands, Tierra del } \\
\text { Fuego; South Georgia Islands, South } \\
\text { Shetland Islands, Antarctica. Ker- } \\
\text { guelen, Bouvet and Crozet Islands }\end{array}$ & $10-400$ & Tierra del Fuego, BB/NMPA \\
\hline Styela magalhaensis Michaelsen, 1898 & $\begin{array}{l}\text { Guaitecas Islands (Chile), Magellan } \\
\text { Strait, Patagonia (Argentina), South } \\
\text { Georgia Islands }\end{array}$ & $99-250$ & $\mathrm{BB} / \mathrm{NMPA}$ \\
\hline $\begin{array}{l}\text { Alloeocarpa incrustans (Herdman } \\
\text { 1886) }\end{array}$ & $\begin{array}{l}\text { Patagonia (Argentina), Malvinas/Falk- } \\
\text { land Islands, Magellan Strait, Tierra } \\
\text { del Fuego, South Georgia Islands }\end{array}$ & $1-150$ & Tierra del Fuego, Staten Island \\
\hline Pyura legumen (Lesson, 1830) & $\begin{array}{l}\text { Mar del Plata and Patagonia (Argen- } \\
\text { tina), Malvinas/Falkland Islands, } \\
\text { Magellan Strait and south Chile, } \\
\text { Tierra del Fuego, South Georgia } \\
\text { Islands }\end{array}$ & $0-115$ & Tierra del Fuego \\
\hline Pyura paessleri (Michaelsen, 1900) & $\begin{array}{l}\text { Malvinas/Falkland Islands, Tierra del } \\
\text { Fuego, South Georgia Islands }\end{array}$ & $2-280$ & Tierra del Fuego BB/NMPA \\
\hline $\begin{array}{l}\text { Pyura pilosa Monniot C and Monniot } \\
\text { F, } 1974\end{array}$ & Kerguelen and Crozet Islands & 585 & $\mathrm{BB} / \mathrm{NMPA} * 100-133 \mathrm{~m}$ \\
\hline $\begin{array}{l}\text { Molgula malvinensis Ärnbäck-Christie- } \\
\text { Linde, } 1938\end{array}$ & $\begin{array}{l}\text { Malvinas/Falkland Islands, Drake Pas- } \\
\text { sage, South Georgia. Kerguelen and } \\
\text { Macquarie Islands }\end{array}$ & $10-400$ & $\begin{array}{l}\text { Tierra del Fuego*, Beagle Channel*, BB/ } \\
\text { NMPA * 65-128 m }\end{array}$ \\
\hline Molgula manhattensis (Dekay, 1843) & $\begin{array}{l}\text { Sweden, Norway, UK, Portugal, Spain, } \\
\text { Morocco, Canadá, USA, Argentina }\end{array}$ & $0-30$ & Tierra del Fuego* $95 \mathrm{~m}$ \\
\hline Molgula pulchra (Michaelsen, 1900) & $\begin{array}{l}\text { Patagonia (Argentina and Chile), } \\
\text { Magellan Strait, Tierra del Fuego, } \\
\text { Drake Passage, South Georgia } \\
\text { Islands. Kerguelen and Macquarie } \\
\text { Islands }\end{array}$ & $13-293$ & $\begin{array}{l}\text { Tierra del Fuego, Beagle Channel, BB/ } \\
\text { NMPA }\end{array}$ \\
\hline $\begin{array}{l}\text { Molgula setigera Ärnbäck-Christie- } \\
\text { Linde, } 1938\end{array}$ & $\begin{array}{l}\text { Patagonia (Argentina), Malvinas/Falk- } \\
\text { land Islands, Tierra del Fuego, Drake } \\
\text { Passage, South Georgia Islands. } \\
\text { Macquarie Island }\end{array}$ & $20-293$ & Staten Island, BB/NMPA \\
\hline Paramolgula gregaria (Lesson, 1830) & $\begin{array}{l}\text { Patagonia (Argentina and Chile), } \\
\text { Malvinas/Falkland Islands, Tierra del } \\
\text { Fuego, South Georgia Islands }\end{array}$ & $1-130$ & Tierra del Fuego, Staten Island \\
\hline
\end{tabular}

BB/NMPA Burdwood Bank/Namuncurá Marine Protected Area

Table 2 Ascidian species richness and percentage of endemism of each province (South American Region)

\begin{tabular}{lclllr}
\hline & SCH & TDF & SAR & MAI & SGI \\
\hline Species richness & 36 & 70 & 34 & 26 & 65 \\
Number of endemic species & 4 & 11 & 3 & 1 & 0 \\
Endemism (\%) & 11.1 & 15.7 & 8.8 & 3.9 & 0 \\
\hline
\end{tabular}

Pooled data from present study and literature

SCH Southern Chile, TDF Tierra del Fuego, SAR Southern Argentina, MAI Malvinas/Falkland Islands, SGI South Georgia Islands richness was found in MAI, where endemism was also low (3.9\%). Species richness and endemism reached intermediate values in $\mathrm{SCH}$ (36 species, $11.1 \%$ endemism) and SAR (34 species, $8.8 \%$ endemism).

The classification analysis showed two groups with more than 50\% similarity (Fig. 2a). Group I comprised TDF and $\mathrm{SCH}$, with 55\% similarity; Group II comprised SAR and MAI with 54\% similarity. The first group plus SGI formed another group with less than $50 \%$ similarity (44\%). The NMDS analysis revealed a relationship between MAI and 


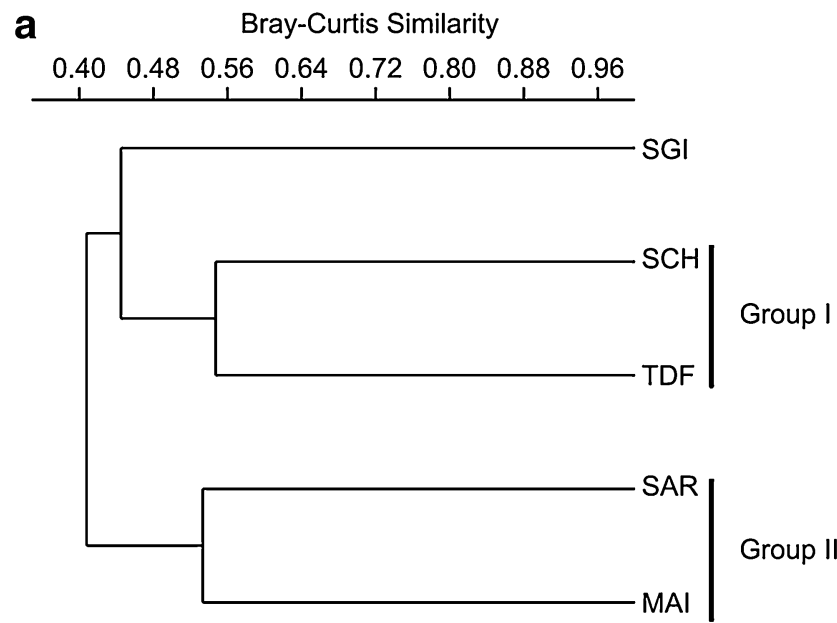

Fig. 2 a Clustering (UPGMA) for ascidian distribution in the different provinces of the South American Region and South Georgia Islands (outgroup), using the Bray-Curtis similarity index, correlation coefficient, 0.7679 ; b two-dimensional NMDS ordination for ascidian distribution in the different provinces of the South American

Table 3 Kulczynski-2 similarity coefficient between different provinces of the South American Region and South Georgia Islands

\begin{tabular}{lllll}
\hline & SCH $(\%)$ & TDF $(\%)$ & SAR (\%) & MAI (\%) \\
\hline TDF & 61.0 & & & \\
SAR & 42.9 & 48.1 & & \\
MAI & 43.1 & 52.7 & 54.3 & \\
SGI & 38.8 & 53.4 & 40.3 & 48.5 \\
\hline
\end{tabular}

Data were pooled from the present study and the literature SCH Southern Chile, TDF Tierra del Fuego, SAR Southern Argentina, MAI Malvinas/Falkland Islands, SGI South Georgia Islands

SAR, and between SCH and TDF, the latter occupying an intermediate position (Fig. 2b).

PERMANOVA did not reveal any significant differences between MAI and the other areas of the South American Region, but MAI was different when compared with the outgroup, SGI. There were significant differences between the remainder of the pairs of groups considered $(F=3.548$; $p=0.0001$ ).

The Kulczynski-2 similarity index confirmed the relationships between provinces (Table 3 ), indicating a higher affinity between SCH and TDF (61\% similarity). TDF was found to have affinity with MAI, SGI, and SAR. The weakest affinity was estimated to be between $\mathrm{SCH}$ and the outgroup, SGI (38.8\% similarity). Considering the four provinces as a whole, the affinity of these and SGI reached $53.6 \%$ similarity. None of the rarefaction curves reached an asymptote (Fig. 3). This suggests that the sampling available so far is not intense enough to include the majority of species likely to be present within each grid cell.

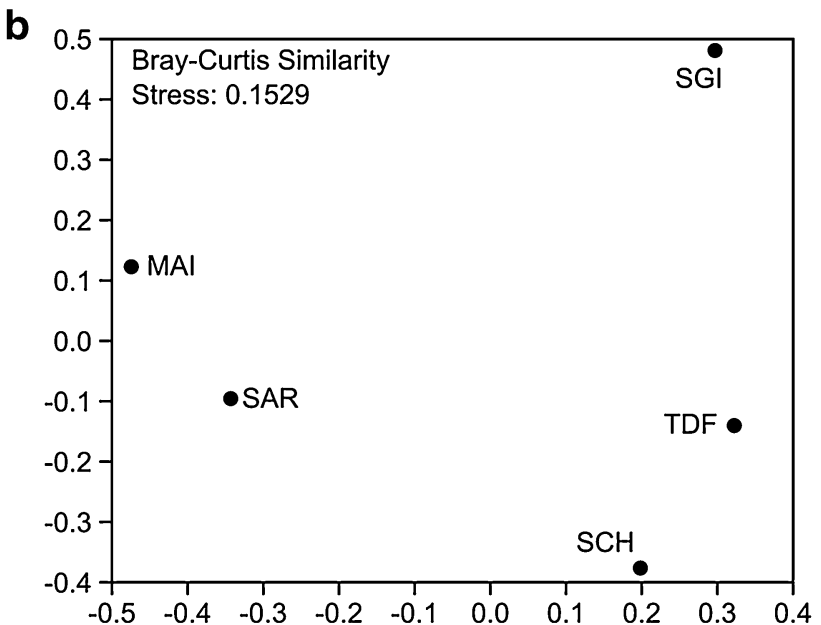

Region and South Georgia Islands (outgroup). Data were pooled from the present study and literature. $S C H$ Southern Chile, $T D F$ Tierra del Fuego, SAR Southern Argentina, MAI Malvinas/Falkland Islands, SGI South Georgia Islands

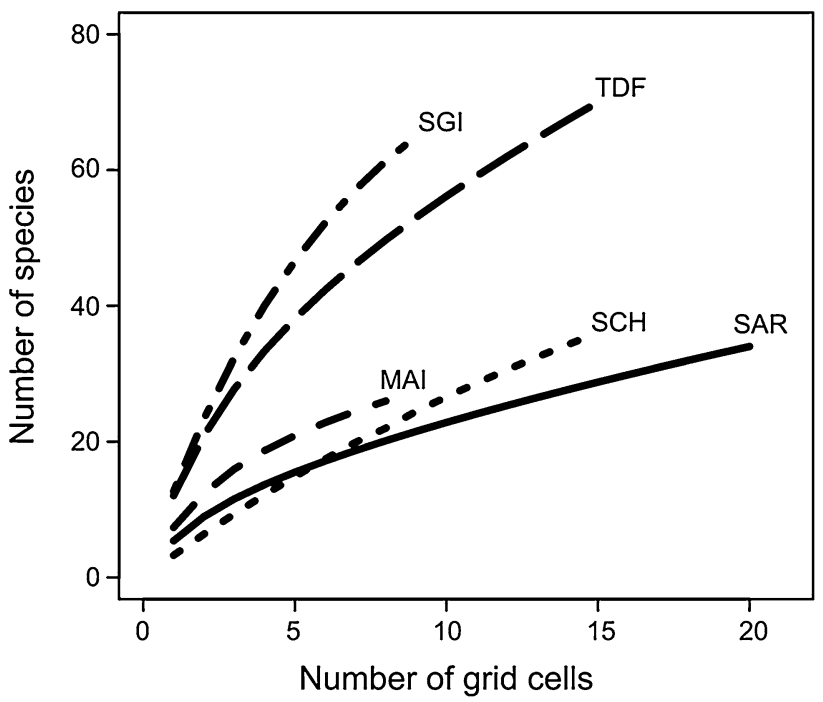

Fig. 3 Rarefaction curves which show the accumulation of ascidian species for each province of the South American Region. SCH Southern Chile, TDF Tierra del Fuego, SAR Southern Argentina, MAI Malvinas/Falkland Islands, SGI South Georgia Islands. Each grid cell was considered as a sampling station, containing all the species recorded in that area. Records of the same species were counted only once within each grid cell

\section{Discussion}

This study has added 20 new ascidian species to the previous biogeographical study carried out in the Magellan area (Primo and Vázquez 2014). Among the 12 ascidian species identified from the "CONCACEN II" campaign, 
three had not been previously reported for the Tierra del Fuego shelf. These are Pyura pilosa, Molgula malvinensis, and Molgula manhattensis. The first occurs in the SubAntarctic islands of Kerguelen, Crozet and the Australian island of Tasmania. Molgula malvinensis was previously recorded in the Malvinas/Falkland, South Georgia, Macquarie, and Kerguelen Islands (Ärnbäck-Christie-Linde 1938; Van Name 1945; Monniot 1978). Considering the widespread distribution of both species in adjacent SubAntarctic areas, that these species are new in the region could be explained by limited sampling.

Molgula manhattensis is a species native to the Northwest Atlantic. In the present study, only a single specimen was found ( $95 \mathrm{~m} \mathrm{depth}$ ) at the mouth of the Magellan Strait. The species was previously considered exotic in the Mar del Plata harbor, S. Atlantic, ca. $38^{\circ} \mathrm{S} ; 57.5^{\circ} \mathrm{W}$ (Orensanz et al. 2002; Fofonoff et al. 2003). In addition to Mar del Plata, the presence of M. manhattensis was reported in the Patagonian ports of San Antonio Este, Puerto Madryn, and Puerto Deseado (Rico et al. 2012; Schwindt et al. 2014). However, it had not been found in other southern harbors, including Ushuaia, where a low number of exotic invertebrate species have previously been found (Schwindt et al. 2014). Invasive ascidians are likely to occur in temperate and warm waters (Shenkar and Swalla 2011), and temperature is one of the most relevant factors that drive ascidian introduction since it determines seasonally programmed reproduction and growth in these animals (Dijkstra et al. 2007). In a recent study, Turon et al. (2016b) did not find any exotic ascidian species in Southern Chile, but ascidian invasions are considered to be of global concern (Lambert 2007), and therefore regular sampling should be made, since their presence is possible in cold areas. Our finding of invasive M. manhattensis in the mouth of the Magellan Strait indicates that this species is a potential invader in the region, particularly in areas such as the Ushuaia harbor and the shelf of Tierra del Fuego.

For an area to qualify as a province, it must contain a level of at least $10 \%$ endemism in two groups of organisms (Briggs 1974). High levels of endemism of benthic invertebrates were registered by Griffiths et al. (2009) in Southern Chile, Tierra del Fuego, Southern Argentina, and the Malvinas/Falkland Islands, indicating that these four areas should be designated as provinces. Results of the present study, however, showed that only TDF (15.7\% endemism) and SCH (11.1\% endemism) could be considered as provinces, and not MAI (8.8\% endemism) or SAR (3.9\% endemism). Considering the latter two areas as a whole, the level of endemism is less than $10 \%$, which could be explained by the homogenizing presence of the Malvinas Current, which enables a wide distribution of fauna. Originating as a branch of the Antarctic Circumpolar Current, the phenomenon would favor the dispersion of Sub-Antarctic biota as far as the South American continental shelf to about $43^{\circ} \mathrm{S}$ and along the slope to $36^{\circ} \mathrm{S}$ (Balech and Ehrlich 2008). Some Sub-Antarctic and even Antarctic ascidian species, such as Aplidium variabile, Aplidium fuegiense, and Sycozoa sigillinoides, have their northernmost limit of distribution in waters as far north as Buenos Aires (Kott 1971).

The present results reflect the lack of homogeneity of ascidian fauna in the Magellan Province, as was recognized previously (Kott 1969a; Ramos-Esplá et al. 2005; Primo and Vázquez 2007) but also partially reflect the division into provinces proposed by Briggs and Bowen (2012). Multivariate analysis showed differences between the four provinces considered. The cluster analysis discriminates two main distribution areas (similarity $>50 \%$ ): Group I (SCH-TDF) and Group II (SAR-MAI) (Fig. 2a). In Group I, PERMANOVA revealed significant differences between $\mathrm{SCH}$ and TDF. This matches the high levels of endemism registered in these areas and thus they could be considered as different provinces. SAR and MAI, however, were found to be similar. Studies performed in the distribution of bryozoans (Barnes and Griffiths 2008) and mollusks (Linse et al. 2006) included SAR and MAI in the same group. Moreover, these provinces show high levels of similarity and low endemism. Other provinces also showed a clear separation of TDF from $\mathrm{SAR}, \mathrm{SCH}$, and MAI, suggesting an intermediate position of TDF in the region, as is also found in the similarity index for ascidians (Table 3), ranging from 48 to $61 \%$.

All these results reinforce the idea of a separation of the South American Biogeographic Region into three Provinces: Southern Chile, Tierra del Fuego, and Southern ArgentinaMalvinas/Falkland. Information on other taxa is fragmentary. For Porifera, Van Soest et al. (2012) showed that the Malvinas/Falkland Islands and the Uruguay-Buenos Aires shelf (ca. $33^{\circ}-38^{\circ} \mathrm{S}$ ) had a weak similarity (around $25 \%$ ). As for Actiniaria, distribution appears to be determined by the influence of Sub-Antarctic water masses (Häussermann and Försterra 2005) but the similarity between SCH and MAI is greater than the similarity between MAI and SAR.

The affinity of SGI with the other four provinces of the South American Region ranged from 38.8\% (SCH) to 53.4\% similarity (TDF) (Table 3). Nevertheless, considering the four provinces as a whole, the similarity index between these and SGI reached 53\%. Previous studies estimated the similarity of SGI with the Magellan Province and found lower values than that calculated in the present work $(45 \%$ by Tatián et al. 2005 and $47.68 \%$ by Primo and Vázquez 2014). This difference can be attributed to the increased data analyzed in the present study, especially with the addition of records in TDF. The similarity between SGI and MAI (48.5\%) and that between SGI and TDF (53.4\%) also stresses the influence of the Malvinas Current on the distribution of species. A similar level of affinity of ascidian fauna was estimated among SGI, the Antarctic Peninsula, and the South Shetland Islands (Monniot and Monniot 1983; Tatián et al. 
2005). These islands were considered the northernmost boundary of the Antarctic and the southernmost limit of the Magellan ascidian fauna (Ramos-Esplá et al. 2005; Tatián et al. 2005). Because of their location, the South Georgia Islands (SGI) would constitute an overlapping area, comprising fauna from both South America and Antarctica, which is dispersed by ocean currents over long periods of time (Arntz 2005). This fact is reinforced by the zero ascidian endemism estimated for SGI (Table 2). Similarly, the species composition of sponges present in the South Georgia Islands gives a mixture of South American and Antarctic species (Downey et al. 2012).

The different sampling efforts over the area, expressed in the differences in species richness between provinces, and the results of rarefaction curves strongly suggest the advisability of continuing sampling and taxonomic and genetic studies on ascidians. Because of their relatively low chance of natural dispersion, ascidians constitute an ideal group of organisms to study biogeographic boundaries and the influence of human transport on the geographical distribution of marine species.

\section{Conclusions}

This study considers ascidian distribution over the Magellan Province for four well-defined areas: Southern Chile (SCH), Tierra del Fuego (TDF), Southern Argentina (SAR), and the Malvinas/Falkland Islands (MAI). These were proposed as biogeographic provinces by Briggs and Bowen (2012). The results showed a low percentage of endemism and a close relationship between SAR and MAI. There is not enough evidence, at the moment, to define these two areas as distinct provinces. In the case of TDF and $\mathrm{SCH}$, their entity is confirmed by their levels of endemism, which were found to be higher than $10 \%$, the minimum needed to qualify an area as a province. Multivariate analysis grouped these two regions but statistical analysis (PERMANOVA) reflected significant differences between them. We propose a separation of the South American Region into three Provinces: Southern Chile, Tierra del Fuego, and Southern Argentina-Malvinas/ Falkland Islands. Further sampling and taxonomical efforts could provide more conclusive data. This study is important in bringing together new evidence of the continued dispersion of invasive ascidian species in this region, which needs continuous monitoring to detect future changes.

Acknowledgements We thank Antonela Taverna, Gaston Alurralde, and three anonymous reviewers for their constructive comments. We are grateful to the crew of the RV "Puerto Deseado". This study was supported by the Consejo Nacional de Investigaciones Científicas y Técnicas (CONICET) and Universidad Nacional de Córdoba (UNC). The work was partially funded by CONICET (PIP No. 20130100508), SECyT-UNC (30720150100406CB), ANPCyT-DNA (PICTO
2010-0119), EU Project IMCONet (FP7 IRSES, Action No. 319718) and IDEAWILD.

\section{References}

Anderson MJ (2001) A new method for non-parametric multivariate analysis of variance. Aust Ecol 26:32-46

Ärnbäck-Christie-Linde A (1938) Ascidiacea Part 1. Further Zool Res Swed Antarct Exp 3:1-54

Arntz WE (2005) The Magellan-Antarctic connection: links and frontiers at southern high latitudes. Summary review. Sci Mar 62:359-365

Ayre DJ, Davis AR, Billingham M, Llorens T, Styan C (1997) Genetic evidence for contrasting patterns of dispersal in solitary andcolonial ascidians. Mar Biol 130:51-62

Balech E, Ehrlich MD (2008) Esquema biogeográfico del Mar Argentino. Rev Invest Desarr Pesq 19:45-75

Barnes DK, Griffiths HJ (2008) Biodiversity and biogeography of southern temperate and polar bryozoans. Glob Ecol Biogeogr 17:84-99

Barroso CX, Lotufo TMDC, Matthews-Cascon H (2016) Biogeography of Brazilian prosobranch gastropods and their Atlantic relationships. J Biogeogr 43:2477-2488

Briggs JC (1974) Marine zoogeography. McGraw-Hill, New York

Briggs JC (1995) Global biogeography. Elsevier, Georgia

Briggs JC, Bowen BW (2012) A realignment of marine biogeographic provinces with particular reference to fish distributions. J Biogeogr 39:12-30. https://doi.org/10.1111/j.1365-2699.2011.02613.x

Castilla JC, Uribe M, Bahamonde N, Clarke M, Desqueyroux-Faundez R, Kong I, Moyano H, Rozbaczylo N, Santelices B, Valdovinos C, Zavala P (2005) Down under the southeastern Pacific: marine non-indigenous species in Chile. Biol Invasions 7:213-232

Clarke A (1996) The distribution of Antarctic marine benthic communities. Ant Res Ser 70:219-230

Clarke A, Crame JA (1989) The origin of the Southern Ocean marine fauna. In: Crame JA (ed) Origins and evolution of the antarctic biota. Geological Society London Special Publications, vol 47. Geological Society, London, pp 253-268

Clarke A, Griffiths HJ, Linse K, Barnes DKA, Crame JA (2007) How well do we know the Antarctic marine fauna? A preliminary study of macroecological and biogeographical patterns in Southern Ocean gastropod and bivalve molluscs. Divers Distrib 13:620632. https://doi.org/10.1111/j.1472-4642.2007.00380.x

Coppari M, Gori A, Rossi S (2014) Size, spatial, and bathymetrical distribution of the ascidian Halocynthia papillosa in Mediterranean coastal bottoms: benthic-pelagic coupling implications. Mar Biol 161:2079-2095. https://doi.org/10.1007/s00227-014-2488-5

Cowman PF (2014) Historical factors that have shaped the evolution of tropical reef fishes: a review of phylogenies, biogeography, and remaining questions. Front Genet 5:394. https://doi.org/10.3389/ fgene.2014.00394

Dijkstra J, Harris LG, Westerman E (2007) Distribution and long-term temporal patterns of four invasive colonial ascidians in the Gulf of Maine. J Exp Mar Biol Ecol 342:61-68. https://doi.org/10.1016/j. jembe.2006.10.015

Downey RV, Griffiths HJ, Linse K, Janussen D (2012) Diversity and distribution patterns in high southern latitude sponges. PLoS ONE 7:e41672. https://doi.org/10.1371/journal.pone.0041672

Fofonoff PW, Ruiz GM, Steves B, Carlton JT (2003) National exotic marine and estuarine species information system. https://invas ions.si.edu/nemesis/. Accessed 12 February 2017

GBIF.org (2017) Global biodiversity information facility. http://gbif. org. Accessed 15 August 2017 
Griffiths HJ, Barnes DKA, Linse K (2009) Towards a generalized biogeography of the Southern Ocean benthos. J Biogeogr 36:162177. https://doi.org/10.1111/j.1365-2699.2008.01979.x

Hammer Ø, Harper DAT, Ryan PD (2001) PAST: paleontological statistics software package for education and data analysis. Paleontolog Electron 4:1-9

Hattab T, Albouy C, Ben RaisLasram F, Loch L, Guilhaumon F, Leprieur F (2015) A biogeographical regionalization of coastal Mediterranean fishes. J Biogeogr 42:1336-1348

Häussermann V, Försterra G (2005) Distribution patterns of Chilean shallow-water sea anemones (Cnidaria: Anthozoa: Actiniaria, Corallimorpharia); with a discussion of the taxonomic and zoogeographic relationships between the actinofauna of the South East Pacific, the South West Atlantic and the Antarctic. Sci Mar 69:91-102. https://doi.org/10.3989/scimar.2005.69s291

Hedgpeth JW (1969) Introduction to Antarctic zoogeography. In: Bushnell VC, Hedgpeht JW (eds) Distribution of selected groups of marine invertebrates in waters south of $35^{\circ} \mathrm{S}$ latitude. Antarctic Map Folio Series, vol 11. American Geographical Society, New York, pp 1-9

Hogg OT, Barnes DKA, Griffiths HJ (2011) Highly diverse, poorly studied and uniquely threatened by climate change: an assessment of marine biodiversity on South Georgia's continental shelf. PLoS ONE 6:e19795. https://doi.org/10.1371/journal.pone.0019795

Kott P (1969a) Ascidiacea. In: Bushnell VC, Hedgpeht JW (eds) Distribution of selected groups of marine invertebrates in waters south of $35^{\circ} \mathrm{S}$ latitude. Antarctic Map Folio Series, vol 11. American Geographical Society, New York, pp 43-44

Kott P (1969b) Antarctic Ascidiacea. A monographic account of the known species based on specimens collected under US government auspices, 1947-1963. Antarct Res Ser 13:1-239

Kott P (1971) Antarctic Ascidiacea II. In: Llano GA, Wallen IE (eds) Biology of the antarctic seas IV, vol 17. American Geophysical Union, New York, pp 11-82

Kott P (1974) The evolution and distribution of Australian tropical Ascidiacea. In: Proceedings of the eight international coral reef symposium, vol 1, pp 405-423

Lagger C, Häussermann V, Försterra G, Tatián M (2009) Ascidians from the southern Chilean Comau Fjord (Chordata, Ascidiacea). Spixiana 32:173-185

Lambert G (2007) Invasive sea squirts: a growing global problem. J Exp Mar Biol Ecol 342:3-4

Legeckis R, Gordon AL (1982) Satellite observations of the Brazil and Falkland currents-1975, 1976 and 1978. Deep Sea Res 29:375-401

Linse K, Griffiths HJ, Barnes DKA, Clarke A (2006) Biodiversity and biogeography of Antarctic and sub-Antarctic Mollusca. Deep Sea Res II 53:985-1008. https://doi.org/10.1016/j.dsr2.2006.05.003

Locke A, Carman M (2009) An overview of the 2nd international invasive sea squirt conference: what we learned. Aquat Invasions $4: 5-28$

Ma KCK, Deibel D, Law KK, Aoki M, McKenzie CH, Palomares ML (2017) Richness and zoogeography of ascidians (Tunicata: Ascidiacea) in eastern Canada. Can J Zool 95:51-59. https://doi. org/10.1139/cjz-2016-0087

McClain CR, Hardy SM (2010) The dynamics of biogeographic ranges in the deep sea. Proc R Soc Lond B 277:3533-3546

Millar RH (1960) Ascidiacea. Discov Rep 30:1-160

Miloslavich P, Klein E, Díaz JM, Hernández CE, Bigatti G, Campos L, Artigas F, Castillo J, Penchaszadeh PE, Neill PE, Carranza A, Retana MV, Astarloa JMD, Lewis M, Yorio P, Piriz ML, Rodríguez D, Yoneshigue-Valentin Y, Gamboa L, Martín A (2011) Marine biodiversity in the Atlantic and Pacific coasts of South America: knowledge and gaps. PLoS ONE 6:e14631. https://doi. org/10.1371/journal.pone.0014631
Monniot C (1978) Ascidies phlebobranches et stolidobranches du sud de l'Ocean Indien. Ann Inst Oceanogr Paris 54:171-224

Monniot C, Monniot F (1983) Ascidies antarctiques et subantarctiques: morphologie et biogéographie. Mém Mus Nat Hist Nat Paris 125:1-168

Moreno TR, Barros de Faria S, Rocha RM (2014) Biogeography of Atlantic and Mediterranean ascidians. Mar Biol 161:2023-2033. https://doi.org/10.1007/s00227-014-2483-x

Naranjo S, Carballo JL, García-Gómez JC (1998) Towards a knowledge of marine boundaries using ascidians as indicators: characterizing transition zones for species distribution along Atlantic-Mediterranean shores. Biol J Linn Soc 64:151-177

Orensanz JM, Schwindt E, Pastorino G, Bortolus A, Casas G, Darrigran G, Elías R, LópezGappa JJ, Obenat S, Pascual M, Penchaszadeh P, Piriz ML, Scarabino F, Spivak ED, Vallarino EA (2002) No longer the pristine confines of the world ocean: a survey of exotic marine species in the Southwestern Atlantic. Biol Invasions 4:115-143. https://doi.org/10.1023/A:1020596916153

Pereyra PJ, Narvarte M, Tatián M, González R (2015) The simultaneous introduction of the tunicate Styela clava (Herdman, 1881) and the macroalga Undaria pinnatifida (Harvey) Suringar, 1873, in northern Patagonia. BioInvasions Rec 4:179-184

Pereyra PJ, de la Barra P, Gastaldi M, Saad JF, Firstater FN, Narvarte M (2017) When the tiny help the mighty: facilitation between two introduced species, a solitary ascidian and a macroalga in northern Patagonia, Argentina. Mar Biol 164:185. https://doi.org/10.1007/ s00227-017-3202-1

Piola AR, Rivas A (1997) Corrientes en la plataforma continental. In: Boschi E (ed) El Mar Argentino y sus Recursos Pesqueros, 1st edn. Instituto Nacional de Investigación y Desarrollo Pesquero, Mar del Plata, pp 119-132

Primo C, Vázquez E (2007) Zoogeography of the Antarctic ascidian fauna in relation to the sub-Antarctic and South America. Antarct Sci 19:321-336. https://doi.org/10.1017/S0954102007000521

Primo C, Vázquez E (2009) Antarctic ascidians: an isolated and homogeneous fauna. Polar Res 28:403-414

Primo C, Vázquez E (2014) Ascidian fauna south of the sub-tropical front. In: De Broyer C, Koubbi P, Griffiths HJ, Raymond B, Udekemd'Acoz $\mathrm{C}$ et al (eds) Biogeographic atlas of the southern ocean. Scientific Committee on Antarctic Research, Cambridge, pp 221-228

R Development Core Team (2016) R: a language and environment for statistical computing. The R Foundation for Statistical Computing, Vienna

Ramos-Esplá AA, Buencuerpo V, Vazquez E, Lafargue F (1992) Some biogeographical remarks about the Ascidian littoral fauna of the Straits of Gibraltar (Iberian sector). Bull Inst Oceanogr (Monaco) 9:125-132

Ramos-Esplá AA, Cárcel JA, Varela M (2005) Zoogeographical relationships of the littoral ascidiofauna around the Antarctic Peninsula in the Scotia Arc and in the Magellan region. Sci Mar 69:215-223. https://doi.org/10.3989/scimar.2005.69s2215

Rico A, Peralta R, López Gappa J (2012) Succession in subtidal macrofouling assemblages of a Patagonian harbor (Argentina, SW Atlantic). Helgol Mar Res 66:577. https://doi.org/10.1007/s1015 2-012-0293-4

Robertson DR, Cramer KL (2014) Defining and dividing the greater Caribbean: insights from the biogeography of shorefishes. PLoS ONE 9:e102918. https://doi.org/10.1371/journal.pone.0102918

Sanamyan K, Schories D (2003) Ascidians from the Strait of Magellan. J Ichthyol Aquat Biol 7:89-96

Schories D, Sanamyan K, Sanamyan N, Díaz MJ, Garrido I, Heran T, Holtheuer J, Kohlberg G (2015) Geographic ranges of ascidians from Antarctica and the southeastern Pacific. Adv Polar Sci $26: 8-23$ 
Schwindt E, López Gappa J, Raffo MP, Tatián M, Bortolus A, Orensanz JM, Alonso G, Diez ME, Doti B, Genzano G, Lagger C, Lovrich G, Piriz ML, Méndez M, Savoya V, Sueiro MC (2014) Marine fouling invasions in ports of Patagonia (Argentina) with implications for legislation and monitoring programs. Mar Environ Res 99:60-68

Shenkar N, Swalla BJ (2011) Global diversity of ascidiacea. PLoS ONE 6:e20657. https://doi.org/10.1371/journal.pone.0020657

Spalding MD, Fox HE, Allen GR, Davidson N, Ferdaña ZA, Finlayson M, Halpern BS, Jorge MA, Lombana A, Lourie SA, Martin KD, McManus E, Molnar J, Recchia CA, Robertson J (2007) Marine ecoregions of the world: a bioregionalization of coastal and shelf areas. Bioscience 57:573-583. https://doi.org/10.1641/B570707

Tatián M, Antacli JC, Sahade R (2005) Ascidians (Tunicata, Ascidiacea): species distribution along the Scotia Arc. Sci Mar 69:205-214

Tatián M, Schwindt E, Lagger C, Varela MM (2010) Colonization of Patagonian harbors (SW Atlantic) by an invasive sea squirt. Spixiana 33:111-117
Turon X, Cañete JI, Sellanes J, Rocha RM, López-Legentil S (2016a) Ascidian fauna (Tunicata, Ascidiacea) of subantarctic and temperate regions of Chile. Zootaxa 4093:151-180

Turon X, Cañete JI, Sellanes J, Rocha R, López-Legentil S (2016b) Too cold for invasions? Contrasting patterns of native and introduced ascidians in subantarctic and temperate Chile. Manage Biol Invasions 7:77-86. https://doi.org/10.3391/mbi.2016.7.1.10

Van Name WG (1945) The North and South American ascidians. B Am Mus Nat Hist 84:1-476

Van Soest RW, Boury-Esnault N, Vacelet J, Dohrmann M, Erpenbeck D, De Voogd NJ, Santodomingo N, Vanhoorne B, Kelly M, Hooper JN (2012) Global diversity of sponges (Porifera). PLoS ONE 7:e35105. https://doi.org/10.1371/journal.pone.0035105

Zhan A, Briski E, Bock DG, Ghabooli S, MacIsaac HJ (2015) Ascidians as models for studying invasion success. Mar Biol 162:24492470. https://doi.org/10.1007/s00227-015-2734-5 